\title{
The Dynamics of Social Inequality in the Kali Gandaki 'A' Dam Project in Nepal: The Politics of Patronage
}

\author{
Kavita Rai
}

\section{Introduction: Dams, development and social inequalities}

$\mathbf{O}$ ne of the argumentsin theimplementation of dam projects is that the benefits will ultimately lead to a win-win situation for all. Large dams in particular are viewed as panacea for the pervasive poverty in the Himalaya-Ganga (Dixit 1994).

Critics of this argument counteract by arguing that people in rural areas are not winning because they receive little direct benefits. Displacements of local families from dam interventions are also critiqued as a price paid for development. Ethical questions are often raised because of the inequitable distribution of benefits and affected people being more vulnerable or worse off (Cernea 2000). Meanwhile, hierarchical relationships of patronage between state bureaucrats and locals, class and other striations also bring about disputes, unequal resettlement and compensation provisions and take more time to negotiate (Gandhi 2003). Within this context, state policies and laws provide the framework for compensating the people affected directly and indirectly. However, the main assumption as taken here is that the hierarchical structure of the Nepalese state and society and the ubiquity of patronage politics will negatively affect even those development programmes that aim at inclusion and redistribution. This hierarchical structure emerges out of a complex social structure where caste, ethnicity and class do not fit into neatly structured divisions. Baral (2000) views inequalities to stem from a hierarchical state that thrived on a system of patronage that has been historically and socially exploitative in nature with the ruling classes enjoying the benefits.

With social inequalities and patronage inherent in Nepali society, development processes are, therefore, apt fields for their manifestation. Dam interventions are not exempt. Equity issues are gaining importance. As the World Commission for Dam report (2000:120) points out, 'the emergence of equity as a critical ingredient of development underlines that this "balance sheet" approach is unacceptable as it ignores the typical mismatch between the distribution of the gains and losses of a project across different societal groups'.

What, then, are the ground realities in the case of Nepal? What are the outcomes in terms of equality/ inequality when large hydropower plants are implanted upon local communities vis-à-vis the distribution of resources-financial and natural (of land and water)? This paper attempts to link in answers to these questions focusing on patronage relations in the Kali Gandaki (KG) 'A' project area. Before unfolding the research assumptions to these questions, the following section will briefly explain the concepts of patronage.

\section{The anthropology of patronage (clientelism)}

The interplay between relational inequalities and distributional inequalities ${ }^{1}$ can be studied within the framework of patron-client relationships. Patronage (used interchangeably with clientelism, a term used by anthropologists) is important because it links the strata based on class, ethnicity and class together, especially in the political process ${ }^{2}$. The word 'patron' is derived from the Spanishpatrón, a person of power, status, authority and influence, while the client is economically and politically weaker (Hall 1977:510). Landé defines a patron-client relation as 'a vertical dyadic alliance; i.e., an alliance between two people of unequal status, power or resources each of whom finds it useful to have as an ally someone superior or inferior to himself' (1977:xx). In such a relationship, the superior member is the patron and the inferior member his client. In addition to unequal status, influence and a relationship based on reciprocity, Powell (1970) adds that patron-client relationship rests on a face-to-face contact between the two parties. Significant amount of research on clientelism were conducted around peasant societies by anthropologists and political scientists (see Swartz 1968; Lemarchand and Legg 1972; Scott 1976; Schmidt et al 1977; Popkin 1979). Later works on patron-client relations focussed on a wider political, historical and contemporary global coverage (see Eisenstadt and Lemarchand 1981; Roniger and Günes- 
Ayata 1994). Patronage and clientelism existed, according to these researchers, in the absence of strong states but then stealthily crept into development processes. In Nepal, there have been no specific attempts to study patronage, although Bista (1991) wrote extensively about chakari, a manifestation of clientelism. Like Bista, other social and political scientists often incorporate patronage and clientelism within a wider work on social or political development.

In this paper, the politics of patronage in the KG 'A' site will be explored through the concepts of patronage used by Scott (1976) and Popkin (1979) mainly because of the commonality of 'rural' settings, inclusive of highly structured patronage relations amongst social groups. J ohn Scott (1976), in theMoral Economy of the Peasants, captures the dynamics of motivations of people that sustain relational and distributive inequalities. Scott argues that peasants and elites are moral and less calculating in precapitalist settings. He believes that the justification of any hierarchy of status and power implies the creation of role obligations that carry moral weight. The subordinate groups accept inequalities because their patrons provide social and material guarantees in return for labour, services and loyalty. Patrons provide these guarantees under scarcity of labour and competition from other patrons. Their mutual interests bind patrons and clients together. They develop a normative framework on this basis. Patrons who do not adhere to this subsistence ethic are exploitative and unjust. When patrons opt out of this frame, peasants resist and rebel because the moral contract is broken. For Scott, stratification originates from capitalism and the entry of markets.

Popkin (1979), on the other hand, made a competing rational political economy thesis in his examination of village economy and politics in precolonial Vietnam. He argues that individual choice and decision-making form the core concepts on why groups of individuals decide to adopt some norms while rejecting others. Subordinate groups act in their individual self-interest even without markets and will opt out of a clientelistic relationship on assessing their own individualistic goals. Popkin's political economy approach argues that norms are malleable, renegotiated and shifted in accordance with considerations of power and strategic interactions among individuals. The assumption is that a peasant is concerned with his/ her own and his/her family's welfare and security, thereby being self-interested and rational.

In terms of the effects of development projects on patron-client relations, however, the two approaches of Scott and Popkin make two different predictions that are taken into account here. Both predict different outcomes of miniaturization and proletarization (the social consequences of the project). Development projects will benefit patrons more because these have the political capital necessary to establish relationships with project staff. Following Scott's and Popkin's approach, it is hypothesized that there will bea 'trickle down' effect: the clients will also profit, since the patrons will hand some of the benefits to their followers. Alternately, through development intervention, new patronage relations will form linking the development stateand locals in new ways to create new dependencies. Taking Popkin's rationality argument, it is also hypothesized that the long term consequences of project intervention, should ideally, be less social hierarchy, less reliance on patronage clan and lineages, less patriarchy, more individual and geographical space mobility'.

\section{Methodology}

A brief conceptual framework adapted from Stern, Ostrom et al (2002:452) to correlate the variables is put forward to further the hypothesis. Given the ecological and social complexities of dam intervention, this framework helps explain and explore the causality of relationships for meaningful theoretical propositions. It tries to explain how social inequalities and patronage politics influence the individual's access to information and decisionmakers and how the inequality of access determines the distribution of compensation and other resources controlled by the dam project.

\section{Dependent variable: Outcomes}

Outcomes are the dependent variables, which are of importance to the resource users who may beaffected by interventions and resource conditions and usage. To examine this variable, inequalities were measured or observed based on the delivery, benefits and distribution of financial compensation resulting from loss of land. Additionally, the benefits from project employment, income generation projects and recruitment of labour in the project site during construction and post construction phases were also examined.

\section{Independent variables: Social inequality (patron-client relations)}

The hypothesis is concentrated on social structure variables and the various relationships through information access and political networks. Patronclient relations and factionalism based on political patronage were pursued as the independent variable.

\section{Research methods}


The research took a case study approach focusing on the local population affected by the 144 MW Kali Gandaki 'A' dam project, Nepal's largest hydropower plant (to date). The collection of secondary data and

\section{Independent Variable}

Social Inequality: Patron Client relations (moral or rational political economy, political factions).

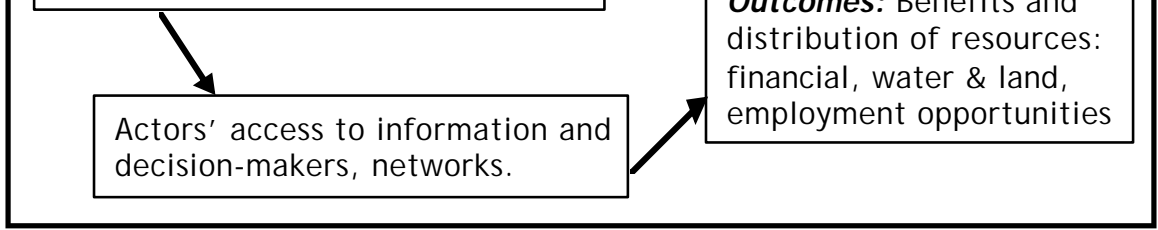

Figure 1. Conceptual Framework (adapted from Stern, Ostrom et al 2002)

field research took place between September 2002 and J uly 2003. Time was allocated to collect projectrelated information, conduct empirical fieldwork, input data, and write field notes. Semi-structured interviews were conducted with relevant experts and personnel from the capital Kathmandu and the Nepal Electricity Authority (NEA) ${ }^{3}$, the main implementing organization. The two most affected villages of Mirmi, where the dam is located, and Beltari, with the powerhouse, both in the central Nepal district of Syangja, were taken as field sites. People who lost a major share of their land to the project came from these two villages. Members from the higher Bahun (Brahmin) caste, the ethnic Magars, and the lower caste groups of Damai, Sunuwars and Kamis, were all interviewed as they were all affected by the KG 'A' project. To gather relevant data on issues of environmental equity of natural resource sharing (mainly the river), interviews were carried out among the Bote fishing communities downstream along the $50 \mathrm{~km}$ river loop and upstream of the dam.

A major part of fieldwork was spent conducting qualitative ethnographic research. The intense community antagonism towards researchers at this stage did not allow for quantitative research. They were suffering from a 'survey burnout' as the project continuously monitored them for about eight years. Therefore, to attain a true picture of the intervention, responses and outcomes and to build up confidence with local respondents, qualitative research became the key method. In addition, key informants (local people as well as current and former project officials) were the major sources of information. After some confidence was built up, an eight-page questionnaire was administered to 108 households that constituted $50 \%$ of those most affected in terms of land loss. These families were categorized by the project as seriously project-affected families (SPAFs) and project-affected families (PAFs).

\section{General extent of the Kali} Gandaki ' $A$ ' dam intervention

In the case of hydropower intervention in Nepal, the law assigns the right over water exclusively to the state. Similarly, in the case of private property, the law of eminent domain ${ }^{4}$ allows the state to acquire private property against compensation only in the public interest. Both private and guthi ${ }^{5}$ lands were acquired in the case of the KG 'A' project. NEA acquired about 53.7 ha (1054 ropanis ${ }^{6}$ ) of land and 57 houses for the access road to the dam and powerhouse sites. A further 148.62 ha was acquired (of which 94.2 ha was private and guthi lands) for the main facilities that include the dam, the powerhouse and the project officesites. In addition, 13 houses, 20 cowsheds and one water collection pond were acquired. Out of the total compensation amount of NRs 30.43 million (US\$ 0.54 million) of compensation, almost 95\% (NRs 30.24 million) had been disbursed (KGEMU 2002).

In terms of resettlement in the $\mathrm{KG}$ ' $\mathrm{A}$ ' project, there were no cases of homelessness. Sixteen Bote (an indigenous fisher community) households whose lands and houses had been earlier appropriated were considered for resettlement. Resettlement was novel to this project, as it did not exist in past hydropower compensatory packages. Cash compensation was the main mode of compensation for land acquired by the NEA. Land for land was not an option. An acquisition, compensation and rehabilitation plan (ACRP) was developed as a pre-project document following the process established in the Land Acquisition Act of 1977 of Nepal. In accordance with the same Act, the chief district officer led a Rate Fixation Committee. Market prices of the area, government rate and gradations of land were the three determining factors used to set compensation rates (KGEMU 2002). Land compensation rates changed three times because the existing rules and laws did not match real land valuations and negotiations took place between local leaders and the compensation committee.

Compensation processes required that all those whose lands were appropriated had to produce land title papers to receive the compensation. All individuals who lost $50 \%$ or more of legally registered land and/ or their living quarters were declared as SPAFs (263 families in total) and those losing less than 


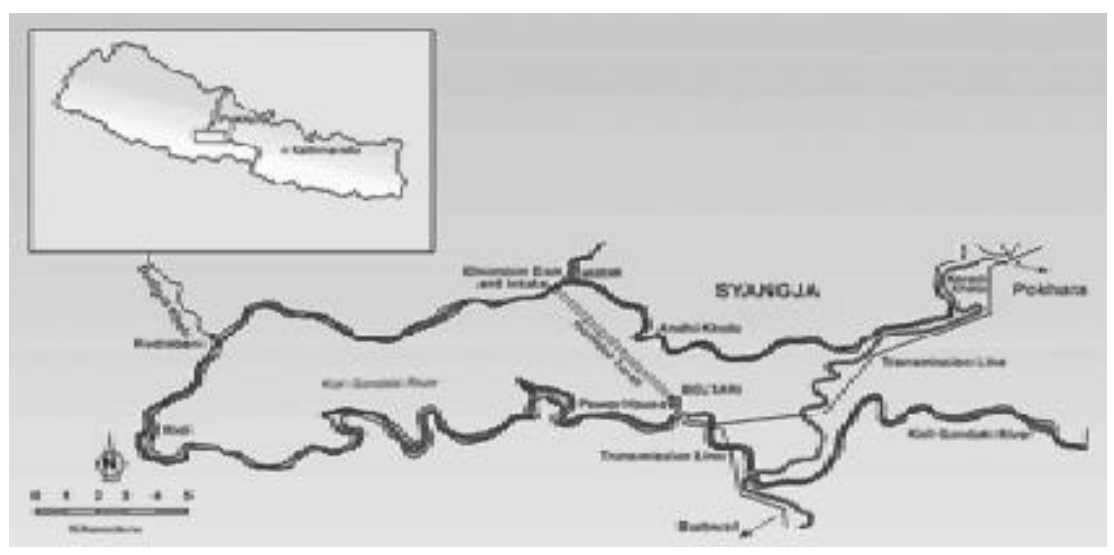

Figure 2. Map of the Kali Gandaki 'A' Hydroelectric Project site (source: The Nepali Times, Kathmandu, \#176, 26 December 2003) of the hierarchical informal institutional structure within the village.

Both hypotheses on clientelism were confirmed in the study as clients benefited mainly through patronage politics. In the case of the Kali Gandaki 'A' intervention, as prominent political party and village leaders lost the major share of their land, it made a crucial difference in the determination of outcomes. Compensation was low in the first acquisition process, that of the access road. Once the patrons (high caste or ethnic group leaders) formed a proper base of knowledge and with $50 \%$ of land were categorized as PAFs ( 1205 families in total). The same criteria were applied for land acquisition for both the road access and the main facilities (dam, powerhouse and offices). The average land-holding size of an affected family was .46 ha to 1.5 ha; often equally divided between irrigated and non-irrigated land.

As part of the mitigation strategy of the Environmental Impact Assessment Plan, at least one person from the affected families was to be provided employment in the project. The Kali Gandaki monitoring unit provided a list of these families to the contractors for job employment. As of May 2001, a total of 2,132 persons were employed in the project of which 1,012 (47.45\%) were from the local area. Altogether, individuals from 94 SPAFs and 190 PAFs were employed in the project.

\section{Empirical evidence to theoretical proposition}

Patron-client relations commonly found in the KG ' $A$ ' areas manifested mainly through three patronage systems: traditional money lending patronage systems, caste based patronage and political patronage, based on political affiliation. In a nascent democracy, ${ }^{7}$ political party leaders are chosen at ward and regional levels forming crucial patrons linking them to the state. According to Pfaff-Czarnecka (2000), political parties are often viewed as best suited allies to the state, which increasingly interferes or provides for the people. In the KG 'A' areas, political leaders as well as government officials-members of Village Development Committees (VDCs) and the District Development Committee (DDC) ${ }^{8}$-played important roles as intermediaries between their followers and project interventionists especially before the dam intervention. However, during the project construction period, competition, especially for employment, grew. Apart from political leadership, social and village elders formed the core their own interests, they raised voices and negotiated with project officials, state bureaucrats and formed alliances to set a higher amount of compensation suited to the changed land economy after the project

As for the project officials, they could capture the local elite. Project officials relied on the influence of local social and political leaders at the beginning of the project period, particularly to mediate with the whole community. This worked for some time. In the whole process, clients or poorer people benefited through their leaders and patrons, both social and political. However, akin to Popkin's assumptions, the slow invasion of a cash economy and the patronage of influential officers started to break this influence. It was mostly through the local VDC or DDC leaders, political parties or elites that families and individuals started to channel influence to gain employment and other benefits.

One of the first dismantling of local power channels resulted from the new-found alliance between local leaders and project officials. The selfinterest of leaders led to the decay of previously existing loyal relations of political and social patronage. Clients opted out of their loyalties to their patrons, especially political leaders, to forge their own alliances with NEA officials, contractors and state bureaucrats, thus supporting Scott's moral economy argument. Alliances with the intervening actors were built particularly to provide jobs for their family members. A majority of the respondents (60\%) said that they have a direct relation with project staff rather than through political or social affiliations. Project officials and outside contractors often took over the role of the 'patrons'. With these alliances grew a new set of relationships, not necessarily fully reciprocal but nonetheless with some reciprocity in the form of trust and loyalty to the project itself. While some respondents who gained fully from the project emphasized their loyalty and positive attitude to the intervention. 
dam intervention, others who had not received continued support, particularly in the form of jobs from officials, feel a sense of betrayal. Individualistic gains were found to be more common, supporting Popkin's political economy argument.

The hypothesis that thelong-term consequences of a project intervention would ideally, be less social hierarchy, less reliance on clan and extended family, less patriarchal and more individual and geographical space mobility were also partially confirmed. In the most affected villages of Beltari and Mirmi, large clans and patronage systems existed. After the loss of land in these villages, cooperation and cohesion among members were found to be weak, as pointed out earlier. In the presence of scarce resources and with competition, most of the respondents identified with their own immediate nucleated family rather than the larger extended family or clan. The provision of cash as compensation is one of the main reasons leading to this fraction. While earlier elder patriarchs had total control and it was often difficult to divide land easily between brothers, after land acquisition it was easier for family members to take their share of the cash and opt out of the extended family. The situation remained similar in all Bahun, Magar and Bote families. This partly supports Scott's thesis that peasants insured themselves socially through reliance on own kin and friends rather than the state (for example, DDC/VDC members).

Similarly, old forms of political control (parties) and patronages disappeared; individualism was on the rise. Project officials and contractors weakened the position of the local social and political leaders through petty contracting, thus tilting support towards them as local communities distrusted their leaders. This led many individuals to develop new relationships, especially with project officials and contractors of the project, thus supporting Popkin's rationality argument.

\section{Conclusion}

Despite the implementation of policies and laws, relationships between the local powerful people and dam project interventionists shaped outcomes towards the former's favour, especially under scarce resource constraints. Linkages within and to the corridors of power (both new and old patronage) were important to access employment or project benefits. Participatory and interactive institutional processes need to be developed further, particularly by the implementing agency, in order to lower unequal outcomes.

From the study, it was concluded that the moral economy approach is well-suited in areas with active functioning agrarian structures. Scott's moral economy provides insight into peasant life with strong land-labour relations and sustenance based on the subsistence ethic. In the KG ' $\mathrm{A}$ ' sites, after almost a decade of project interventions and the entry of a wider set of national and international actors, new institutional arrangements had crept up. Markets had broadened, particularly with the additional road network, and the cash economy tilted eventually in favour of Popkin's rational economy model. One lesson is clear: that old forms of patronage will metamorphose into new ones and power relations will continue to play a major role especially in development interventions in rural areas. Developing transparent policies and programmes are one way of enhancing equality of outcomes amongst various social and gender groups. Otherwise, the intricacies of power within social relationships may hamper progress and equitable solutions at the local level.

Kavita Rai is an anthropologist working in the area of energy for sustainable development. The research was carried out in fulfillment of her $\mathrm{PhD}$ dissertation, entitled Dam Development: The Dynamics of Social Inequality in a Hydropower Project in Nepal (Rai 2005). The data in this article are derived from field research carried out in 2002-2003 on the Kali Gandaki 'A' Hydroelectric Project. The research was funded by the Deutscher Akademischer Austausch Dienst, Germany, through the Center for Development Research, in Bonn. The article summarizes two theoretical concepts and results of the research.

Corresponding address: kavita_rai@yahoo.com

\section{End notes}

1. Béteille (1983:1) differentiates between relational and distributional inequality. Relational inequalities are inherent in relations amongst people. Some are deemed superior, and others subordinate, with the division of people into categories along caste, ethnic, class and gender lines. Distributional inequalities, however, concern disparities in the distribution of material resources such as income and wealth.

2. Patron-client studies conducted since the mid-60s have shown interesting insights into political life in rural communities.

3. Nepal Electricity Authority (NEA), created on 16 August 16 1985, is responsible for planning, constructing, operating and maintaining all generation, transmission and distribution facilities in Nepal's power system both interconnected and isolated.

4. Eminent domain is defined as 'the power of a nation or a sovereign state to take or to authorise the taking of private property for public use without 
the owner's consent, conditioned upon the payment of compensation' (Bhattarai 2001:52).

5. Guthi land grants, are religious endowments (Ramirez 2000a) or for social charity purposes; e.g. public schools and hospitals (New Era 1988).

6. 1hectare land equals 19.6 ropani.

7. Nepal became a multi-party democracy in 1990.

8. The Village Development Committee (VDC) is the lowest administrative political unit at the village level, and at the district level is the District Development Committee (DDC) working between parliament and local bodies. Committee members often have an affiliation to a political party.

\section{References}

Baral, L.R., 2000, Clash of values: Governance, political elites and democracy in Nepal, pp.54-89 inDomestic Conflict and Crisis of Governability in Nepal,D. Kumar (ed.), Kathmandu: Centre for Nepal and Asian Studies, Tribhuvan University.

Béteille, André (ed.), 1983, Equality and Inequality. Theory and Practice, New Delhi: Oxford University Press.

Bhattarai, Ananda Mohan, 2001, Displacement and Rehabilitation in Nepal: Law, Policy and Practice, New Delhi: Anmol Publications.

Bista, Dor Bahadur, 1991, Fatalism and Development: Nepal's Struggle for Modernization, Calcutta: Orient Longman.

Cernea, M. Michael and McDowell, Christopher (eds.), 2000, Risks and Reconstruction: Experiences of Resettlers and Refugees, Washington, DC: The World Bank.

Cernea, M Michael, 2000, Risks, safeguards, and reconstruction: A model for population displacement and resettlement, pp.11-55 in Risks and Reconstruction: Experiences of Resettlers and Refugees, M.M. Cernea and C. McDowell (eds.), Washington, DC: The World Bank.

Dixit, Ajaya, 1994, Water projects in Nepal: Lessons from displacement and rehabilitation, Water Nepal (Journal of the Nepal Water Conservation Foundation), 4(1).

Eisenstadt, Samuel N. and Lemarchand, Rene (eds.), 1981, Political Clientelism, Patronage and Development, Thousand Oaks, CA: Sage Publications.

Hall, Anthony, 1977, Patron-client relations: Concepts and terms, pp.510-512 in Friends, Followers and Factions: A Reader in Political Clientelism, S.W. Schmidt, J .C. Scott, C. Landed and L. Gusty (eds.), Berkeley and Los Angeles, CA: University of California Press.

KGEMU (Kali Gandaki Environmental Management Unit) and MKI (Morrison Knudsen International), 2002, Impoverishment Risks Monitoring and
Management in Kali Gandaki 'A' Hydroelectric Project: A Social Synthesis Report, Beltari, Syangja District, Nepal: Nepal Electricity Authority, Kali Gandaki 'A' Hydroelectric Project.

Lande, Carl H., 1977, The dyadic basis of clientelism, pp. xiii-xxxvii in Friends, Followers and Factions: A Reader in Political Clientelism, S.W. Schmidt, J .C. Scott, C. Landed and L. Gusty (eds.), Berkeley, CA: University of California Press, Berkeley and Los Angeles, CA: University of California Press.

Lemarchand, Rene and Legg, Keith, 1972, Political clientelism and development: A preliminary analysis, Comparative Politics, 4(2):149-178.

Pfaff-Czarnecka, J ., 2000, Complex communities in Nepal-Himalaya, or: 'Solidarity'-A global category and a way of life, pp.457-477 in Nepal: Myths \& Realities, R. Thapa and J . Baaden (eds.), New Delhi: Book Faith India.

Popkin, Samuel L., 1979, The Rational Peasant: The Political Economy of Rural Society in Vietnam,Berkeley and Los Angeles, CA: University of California Press.

Powell, J ohn D., 1970, Peasant society and clientelist politics, American Political Science Review, 64(2) :411429.

Rai, Kavita, 2005, Dam Development: The Dynamics of Social Inequality in a Hydropower Project in Nepal, Gottingen, Germany: Cuvillier Verlag.

Roniger, Luis and Günes-Ayata, A. (eds.), 1994, Democracy, Clientelism and Civil Society, Boulder, CO: Lynne Reinner.

Schmidt, Steffan W., Scott, J ames C., Lande, C. and Guasti, Laura (eds.), 1977, Friends, Followers and Factions: A Reader in Political Clientelism, Berkeley and Los Angeles, CA:. University of California Press.

Scott, J ames S., 1976, The Moral Economy of the Peasant: Rebellion and Subsistence in Southeast Asia, New Haven, CT: Yale University Press.

Scott, J ames S., 1977, Patron-client politics and political change in Southeast Asia, pp.15-28 in Friends, Followers and Factions: A Reader in Political Clientelism, S.W. Schmidt, J .C. Scott, C. Landed and L. Gusty (eds.), Berkeley and Los Angeles, CA: University of California Press.

Stern, C.P., Dietz, T., Dolsak, N., Ostrom, E. and Stonich, S., 2002, Knowledge and questions after 15 years of research, pp.443-490 in The Drama of the Commons, E. Ostrom, T. Dietz, N. Dolsak, P. Stern, S. Stonich and E. Weber (eds.), Washington, DC: National Academy Press.

Swartz, J Marc (ed.), 1968, Local Level Politics: Social and Cultural Perspectives, Chicago: Aldine.

World Commission for Dams (WCD), 2000, Dams and Development: A New Framework for Decision Making (Report on the World Commission on Dams), London, UK: Earthscan Publications. 